\title{
NĖŠČIŲJŲ SVEIKATOS RAŠTINGUMO UGDYMO GALIMYBIŲ ANALIZE்
}

\author{
Alma Gaupšienė $\dot{1}^{1}$ Jurga Šuminienè ${ }^{1}$, Rimantas Stukas ${ }^{1}$, \\ Jelena Kutkauskiené2, Natalja Fatkulina ${ }^{1}$ \\ ${ }^{1}$ Vilniaus universiteto Medicinos fakulteto Sveikatos mokslu institutas, \\ ${ }^{2}$ Mykolo Romerio universiteto Teisès mokyklos Viešosios teisès institutas
}

Raktažodžiai: motinų sveikatos raštingumas, něščiųu sveikatos priežiūra ir teisinių reglamentų analizè, akušerio kompetencija, COVID-19 infekcija nèštumo metu.

\section{Santrauka}

Motinų informuotumas ir jų sveikatos raštingumas svarbus něščiujų sveikatos priežiūros veiksnys. Šiuo atveju labai svarbus ryšys su sveikatos paslaugų tiekejjais, orientuotas į nepriekaištingą motinos sveikatą, elgseną néštumo metu, nekomplikuotą nėštumo eigą, gimdymą, naujagimio priežiūrą. Lietuvoje nėščiujjų sveikatos priežiūra vykdoma teisès aktuose numatyta tvarka, suteikiant galimybę nėččiosioms pasirinkti sveikatos priežiūros specialistą - gydytoją akušeri ginekologą, šeimos gydytoją, akušerę, esant fiziologinei nèštumo eigai, gimdymui, sveikam naujagimiui. Teisès aktai nurodo sveikatos priežiūros paslaugas nėščiosioms, ambulatorinę priežiūrą (7-8 kartai) esant fiziologinei neštumo eigai bei galimybę néščiajai savo nuožiūra pasirinkti gimdymo stacionarą, atsižvelgiant ị sveikatos būklę. Paslaugos nemokamos (socialiai draustoms pacientėms), kompensuojamos teritorinių ligonių kasų, tačiau nèra nurodyta něščiujų mokymo paslauga, ugdanti sveikatos raštingumą bei galimybẻ lankyti néščiujų mokymo kursus, finansuojant juos iš valstybinių ligonių kasų. Tai palikta něščiosios pasirinkimui, neprivaloma, nereglamentuota, nèra ịteisinto bendro standarto.

Tyrimo tikslas - išanalizuoti Lietuvoje galiojančius teisès aktus, reglamentuojančius nėščiujų priežiūros paslaugų teikimą, motinos sveikatos raštingumo ugdymo galimybes ir ypatumus, akušerio kompetenciją ir galimybes ugdyti motinų sveikatos raštingumą.

Tyrimo rezultatai ir jų aptarimas. Motinų sveikatos raštingumas literatūros šaltiniuose apibrèžiamas kaip asmens socialinių ir pažintinių ịgūdžių visuma, sveikatos raštingumo lygis bei išsilavinimas, siejamas su gera motinų sveikatos žinių ir jų supratimo sąvoka, galimybe gauti naują informaciją ir ja remtis. Motinų sveikatos raštingumas reikšmingas motinos ir naujagimio sveikatos priežiūroje bei sveikatos elgsenoje. Nėščiųu priežiūros reikalavimus nusako Lietuvoje adaptuotos tarptautinio bendradarbiavimo programos, metodikos, algoritmai, Lietuvos sveikatos politika, sveikatos apsaugos ministro įsakymai ir kt. Antenatalinės priežiūros metodikoje nurodomas tikslus vizitų kiekis, esant fiziologiniam nëštumui ir eigai, prioritetu nurodomas nėščiosios supratimas, įsiklausymas, tačiau motinų sveikatos raštingumas neįtrauktas kaip būtina ugdymo priemonè, mokant motinas (tèvus) tinkamos sveikatos elgsenos nëštumo metu, naujagimio priežiūros ịgūdžių. Informaciją vizito metu néščiosios gauna iš šeimos gydytojo ar akušerio-ginekologo, akušerès, tačiau informacija yra ribota dèl vizito laiko trukmès ir kiekio. Sveikatos raštingumo ugdymo procesas, nurodomas kaip veiksmų seka, kurioje sąveikauja tarpusavyje tam tikri elementai: mokymo tikslas ir turinys, ugdymo metodas ir priemonès bei ugdytojo vaidmuo. Motinos sveikatos raštingumo ugdytojo vaidmeni gali atlikti akušerè, tačiau tam tikslui nèra metodikos, nèra bendro standarto, néščiųų mokymai bei kita švietejiška veikla neprivaloma ir nefinansuojama.

\section{Ivadas}

Pasaulyje kasmet miršta daugiau nei 300000 moteru dèl nèštumo ir gimdymo komplikacijų, 2,8 mln. gimusių naujagimių miršta per pirmąsias 28 gyvenimo dienas [6,7]. Europos Sajungoje (ES) gimdyvių mirtingumas vis dar siekia 4,4/100 000, Lietuvoje - 7,5/100 000 gyvų gimusių naujagimių $[25,40]$. Kūdikių vidutinis mirtingumo rodiklis ES - 3,3/1000, Lietuvoje 3,5/1000 gyvų gimusių naujagimių $[25,40]$. Něščiujų, gimdyvių ir naujagimių mirtingumas reprezentuoja ne tik socialinius ir ekonominius Lietuvos rodiklius, bet ir laikomas svarbiu rodikliu, vertinant sveikatos 
sistemos prieinamumą, akušerinès pagalbos paslaugų kokybę bei motinos sveikatos raštingumą $[6,7,25,40]$. Siekiant užtikrinti akušerinių sveikatos priežiūros paslaugų kokybę, Lietuvos sveikatos sistemoje plètojami teisiniai reglamentai, metodikos, algoritmai, tačiau motinos sveikatos raštingumo plètojimui dèmesio neskiriama, tai paliekama motinos požiūriui.

Motinos sveikatos raštingumo sąvoka apibrezžiama kaip pažinimo ir socialiniai ịūdžiai, reikšmingi motyvacijai ir gebejjimui gauti informaciją, suprasti ją ir panaudoti ta linkme, kuri skatina ir palaiko jos ir naujagimio sveikata $[1,14]$. Sveikatos raštingumas ir išsilavinimas igalina motinas rasti ir suprasti informaciją apie sveikatą, sveikatos raštingumo ịūdžiai lemia motinų gebejjimą vertinti sveikatos būklę bei laiku kreiptis ị sveikatos priežiūros ịstaigą. Prevencinè sveikatos priežiūra taip pat siejama su motinų sveikatos raštingumo lygiu [15-19]. Akivaizdu, kad motinų sveikatos raštingumas svarbus veiksnys motinos sveikatos priežiūroje, tačiau Lietuvoje nėra skiriama dèmesio sveikatos raštingumo ugdymui bei finansavimui, todèl būtina gerinti ne tik sveikatos sistemos paslaugų prieinamumą ir kokybę, bet ir plètoti motinos sveikatos raštingumą, sukuriant efektyvų teisinị pagrindą.

Tyrimo tikslas - išanalizuoti Lietuvoje galiojančius teisės aktus, reglamentuojančius néščiųų priežiūros paslaugų teikimą, motinos sveikatos raštingumo ugdymo galimybes ir ypatumus, akušerio kompetenciją ir galimybes ugdyti motinų sveikatos raštingumą.

\section{Tyrimo medžiaga ir metodai}

Literatūros šaltinių paieška buvo vykdoma tarptautinèse medicinos duomenų bazèse PubMed (Medline), Cochrane Library. İ sisteminę apžvalgą įtraukti anglų kalba publikuoti, atsitiktinių imčių kontroliuojami tyrimai, atvejų ataskaitos, atvejų apžvalgos pagal raktinius žodžius ir jų derinius: maternal health literacy, maternal health care, COVID-19 infection during pregnancy. Atlikta Lietuvos Respublikoje galiojančių teisés aktų - ịstatymų, ịsakymų, metodikų, algoritmų, Lietuvos medicinos normos apžvalga ir analizè.

\section{Tyrimo rezultatai}

Motinų sveikatos raštingumas. Sveikatos raštingumas medicinos literatūroje pirmą kartą paminètas 1970 metais [8]. Pirmaji sveikatos raštingumo apibrèžimą suformulavo Jungtinių Amerikos Valstijų (JAV) Sveikatos ir žmonių tarybos departamentas. Apibrēžimas nurodo, kad sveikatos raštingumas - tai individų gebejjimas gauti, įsisavinti ir suprasti pagrindinę informaciją apie sveikatą ir reikalingas paslaugas, siekiant priimti teisingus sprendimus [9]. Gera sveikata daro ịtaką ne tik individui, bet ir šeimai, visuomenei, todèl sveikatos puoselèjimas, sveikos gyvensenos pagrindai ir sveikatos raštingumas turi būti pradètas ugdyti šeimoje ir sveikatos priežiūros įstaigose [10]. Motinos sveikatos raštingumas ir motinos vaidmuo, formuojamas kaip vienetas, atsakingas bei reikšmingas motinos sveikatos elgsenai, siekiant ugdyti ir palaikyti gerą sveikatą [10-13]. Motinos sveikatos raštingumo sąvoka apibrèžiama kaip pažinimo ir socialiniai ịūdžiai, reikšmingi motyvacijai ir gebėjimui gauti informaciją, suprasti ją ir panaudoti ta linkme, kuri skatina ir palaiko jos ir naujagimio sveikatą [14]. Sveikatos raštingumas ir išsilavinimas igalina motinas suprasti informaciją, laiku kreiptis ị sveikatos priežiūros ịstaigą, lankyti sveikatos mokymų mokyklas bei teikia galimybę rinktis sveikatos priežiūros specialistą něštumo priežiūrai $[15,16]$. Nepakankamas sveikatos priežiūros vertinimas yra žalingas veiksnys, o informacijos nesupratimas lemia nepagristus motinu sprendimus, tikètinus blogesnius sveikatos rezultatus $[12,13]$. Reikšmingas derinys stebimas tarp motinos socialinių veiksnių ir sveikatos priežiūros, kai motinų sveikatos raštingumas vertinamas kaip ịūdis, kuris rodo gebejjimą ịtarti ir suprasti pavojingus nèštumo simptomus, laiku priimti sprendimus, susijusius su medicinine sveikatos priežiūra ir pagalba [17]. Motinų sveikatos raštingumo lygis padeda néččajai suprasti néštumo metu kylančius pavojus bei klinikinius simptomus, pasirūpinti savimi, laikytis akušerių ar gydytojų rekomendacijų, nurodančių tinkamą elgseną nèštumo metu, siekiant išsaugoti sveiką ir saugų néštumą $[18,19]$. Motinų sveikatos raštingumo lygis vertinamas trimis įverčiais - žemas, vidutinis, aukštas [20,21]. Žemas motinos sveikatos raštingumas siejamas su daugeliu sveikatos rezultatų - padidejjusiu hospitalizavimu, prasta sveikata, mirtingumu bei didesne tikimybe néštumą pabaigti cezario pjūvio operacijos būdu, ar, gimdant natūraliais gimdymo takais, aukštu tarpvietès plyšimo laipsniu $[6,22]$. Žemo sveikatos raštingumo motinų naujagimiai dažniausiai per anksti gimsta (30-34 néštumo savaitę), išnešiotų naujagimių gimimo svoris ženkliai mažesnis, nei naujagimio gimimo svorio norma, Apgar vertinimo skalès balai žemesni nei 7 [20,21]. Priešingai, aukštas motinų sveikatos raštingumas skatina jas elgtis atsakingai nèštumo metu, tuo sumažinant mirtingumo riziką bei néštumo ir gimdymo problemas [21]. Aukšto sveikatos raštingumo moteru néštumai planuoti, vizitai pas gydytojus - reguliarūs, motinos nelinkusios i depresiją po gimdymo, gimusio naujagimio kūno masès svoris - normos ribose [23-25].

Motinos sveikatos organizavimo principai LR sveikatos politikos kontekste. Lietuvoje siekiant modernios néščiųų, gimdyvių ir naujagimių sveikatos priežiūros bei gerinant sveikatos priežiūros paslaugų kokybę, pirmasis žingsnis žengtas 1991 m., kai buvo pradèti registruoti gimę naujagimiai pagal Pasaulio sveikatos organizacijos (PSO) 
rekomendacijas (naujagimio kūno masè siekè $500 \mathrm{~g}$ ir 22 nèštumo savaites) [2]. 2015 metais Lietuvoje pradèta vykdyti Lietuvos - Šveicarijos bendradarbiavimo programa ligoninėse, siekiant pagerinti sveikatos priežiūros paslaugų kokybę [26]. Programos iniciatyva Lietuvoje sukurtos ir integruotos darbo metodikos, algoritmai, nurodantys tinkamą něščiujų ir naujagimių priežiūrą akušerijos ir neonatologijos sveikatos priežiūros ịstaigoje [26]. Siekdamas pagerinti paslaugų prieinamumą ir kokybę, 2013 metais LR sveikatos apsaugos ministras įsakymu patvirtino Nëščiųjų, gimdyvių ir naujagimių sveikatos priežiūros tvarkos aprašą [27], kuriame nurodoma, jog něšciujų, gimdyvių ir naujagimių sveikatos priežiūra Lietuvoje vykdoma trimis sveikatos priežiūros paslaugų teikimo lygiais, kuriais siekiama užtikrinti akušerijos, něštumo patologijos, naujagimių intensyviosios terapijos ir neonatologijos paslaugų néščiosioms, gimdyvèms ir naujagimiams tinkamumą ir racionaliai naudoti sveikatos priežiūros išteklius, paslaugas teikiant asmens sveikatos priežiūros istaigose (aprašas koreguotas 2018, 2020 m.) [27]. Néščiujų antenatalinès priežiūros metodikoje išdèstytas reikiamas něščiųų vizitu (7-8) skaičius, skiriamas dėmesys néččiujų nusiskundimų išklausymui, klinikinių tyrimui skyrimui bei vertinimui $[16,17]$. Něščiujų siuntimas ị něšciujų mokymus nèra reglamentuojamas ir nevykdomas. Apibendrinant nëščujų sveikatos priežiūros reglamentus, stebima kokybiška něščiujų priežiūra, tinkamas ir tikslus konsultacijų skaičius, reikiamų tyrimų planas, nurodomi asmens sveikatos paslaugų teikimo lygiai, suteikiama galimybė gimdyvei pasirinki specialistą, gimdymo stacionarą, tačiau visiškai nèra reglamentuojami něšciųu mokymai ar kito pobūdžio informacinè švietejiška veikla, kuri leistų néččajai rinktis, dalyvauti bei gauti tinkamą informaciją apie néščiųų mitybą, kūdikio priežiūrą, žindymą ir jo naudą, galimus sunkumus bei jų sprendimo būdus, tinkamą elgseną gimdymo metu, fizinį aktyvumą, psichologinę pagalbą nėštumo ir po gimdymo laikotarpiu. Lietuvos mokslininkai tyre informacijos šaltinius, kuriais rèmėsi něščiosios, ieškodamos informacijos apie sveikatos priežiūrą bei ugdydamos sveikatos raštingumą apimančias savybes. Nustatyta, kad respondentès informacijos dažniausiai ieškojo knygose $(61,82$ proc.) ir internete $(58,18$ proc.), mažiausiai $(5,45$ proc.) minejjo televizijos laidas. Maža dalis respondenčių $(23,64$ proc.) teigé, jog daugiausia dominančios informacijos sužinojo lankydamos „Mamų mokyklèles“ [18-20]. Apie těčių patirtị, ruošiantis tèvystei, Lietuvoje atliktų tyrimų nepavyko rasti. Buvo tiriama néščiųjų nuomone, ieškant informacijos apie něštumo eigą ir naujagimio priežiūrą. 38 proc. respondentų tokios informacijos visai neieškojo, nes nejautè poreikio, nežinojo, kad turi domètis [6]. Apibendrinant LR teisès aktų ir reglamentų kontekstą, stebima, kad nėščiujų priežiūra atitinka Europos sveikatos priežiūros reglamentus, tačiau nėčiujų sveikatos raštingumo ugdymo procesas nevykdomas. Informaciją néččiosios gauna iš šeimos gydytojo ar akušerio-ginekologo, akušerès, vizito metu, tačiau informacija yra ribota dèl vizito laiko trukmès. Gauti išsamią informaciją, lankyti valstybès finansuojamus nėščiujų mokymus, taip ugdant motinos sveikatos raštingumą, galimybès nèra. Australijoje nėščiosioms suteikiama galimybè lankyti nemokamus kūdikių priežiūros kursus bei skiriami šeši vizitai mokymams namuose po gimdymo [31]. Jungtinejje Karalystejje vykdomi něščiosios mokymo kursai nėštumo metu ir laikotarpiu po gimdymo, akušerè vyksta pas motinas ị namus, moko maudyti naujagimį bei kitų praktinių igūdžių. Akušerinè priežiūra vykdoma mènesị po gimdymo ir yra nemokama [33]. Švedijoje vedami nemokami standartizuoti mokymai nëščiosioms. Mokymai vyksta ne tik žodžiu, bet ir technologijų pagalba, rodoma vaizdo medžiaga, praktikai pasitelkiami muliažai. I mokymus ịtraukiami ir tèčiai, mokymai vyksta šeimoms, grupèms, individualiai [32].

Motinos sveikatos raštingumo ugdymo procesas pagal akušerio kompetenciją. Sveikatos raštingumo ugdymas tai procesas, igalinantis individus ar bendruomenę rūpintis savo sveikata bei stiprinti veiksmų kontrolę, siekiant geresnès sveikatos [14,25,29]. Moksliniuose šaltiniuose sveikatos raštingumo ugdymo sistema nurodoma kaip procesas, kuriame sąveikauja tarpusavyje tam tikri elementai: mokymo tikslas ir turinys, ugdymo metodas ir priemonés bei ugdytojo vaidmuo. Lietuvoje akušerès kompetencija iggalina akušerę dalyvauti motinos sveikatos raštingumo ugdymo procese [34,35]. Lietuvos medicinos norma MN 40:2014 „Akušeris. Teisès, pareigos, kompetencija ir atsakomybe்" nurodo, kad akušerè gali savarankiškai teikti akušerinę pagalbą teisès aktų nustatyta tvarka, apimančią moterų sveikatos priežiūrą, prevenciją bei sveiko naujagimio priežiūrą ir vykdyti mokymus pagal savo kompetenciją [35]. Lietuvos Respublikos slaugos praktikos ir akušerijos praktikos įstatymas nurodo akušerijos praktikos veiklos licencijavimą bei tinkamą kompetenciją, vykdant akušerinę veiklą $[35,36]$. Lietuvoje akušerių studijų programos bei studijų metu igytos kompetencijos, praktiniai igūdžiai bei teisès aktų numatyta tvarka leidžia akušerei dirbti savarankiškai bei vykdyti švietejjišką motinų sveikatos raštingumo ugdymo veiklą, skatinant tinkamą motinos sveikatos priežiūrą bei naujagimio poreikių užtikrinimą, tačiau tokia veikla neįtraukta ị néščiosios priežiūros paslaugų paketą, nèra integruoto bendro standarto, nėščiujų sveikatos raštingumo ugdymas neapmokamas valstybinių ligonių kasų.

Něščiujjų sveikatos raštingumo ugdymas COVID-19 pandemijos metu. 2019 m. gruodžio mènesi COVID-19 ligos (koronaviruso infekcijos) protrūkis tapo pasauline grèsme visuomenès sveikatai [37]. $2020 \mathrm{~m}$. vasario $28 \mathrm{~d}$. 
PSO pasauliniu mastu COVID-19 ligos plitimo riziką ịvertino labai aukštu balu [37]. Užsienio literatūroje pandemijos metu stebimas ryškus akušerès vaidmuo švietẻjiškoje COVID-19 veikloje, kai nėščiosioms informacija teikiama internetu, jos mokomos atpažinti pirmuosius COVID-19 infekcijos simptomus, pažinti streso požymius (apetito pokyčiai, dažnas baimès - nerimo dèl nėštumo ir gimdymo jausmas, nekokybiškas miegas) [37,38]. Išdèstomi ir streso mažinimo veiksmai - susilaikyti nuo informacinių laidų žiūrèjimo, informacijos sekimo, dalyvauti akušerès vedamuose nuotolinių konsultacijų seminaruose, bandyti medituoti, giliai kvėpuoti, stengtis atsiriboti nuo esamos situacijos, telefonu ar vaizdo priemonėmis bendrauti su draugais, šeimos nariais, dalyvauti tèvų vaizdo susitikimuose, sportuoti, pakankamai miegoti, pastebejjus nerimo ar liūdesio simptomus, kreiptis pagalbos ị sveikatos priežiūros specialistus [37-39]. Lietuvoje nëščiosioms Sveikatos apsaugos ministerijos (SAM) internetinejje svetainëje skirta mokomoji informacija „Covid -19 infekcija ir nèštumas“. Mokoma atpažinti pirmuosius COVID-19 infekcijos simptomus (kosulys, karščiavimas $<37,0{ }^{\circ} \mathrm{C}$, silpnumas) bei nurodoma néščiosios prièmimo ị stacionarą tvarka [39]. Naujagimio žindymo galimybės išdèstytos atsižvelgiant ị klinikinę motinos būklę. Sergant sunkios formos COVID-19 infekcija, naujagimis nežindomas motinos pienu. Nuoseklūs veiksmai užtikrina něščiujų sveikatos raštingumo ugdymą bei tinkamą néščiujų sveikatos priežiūros elgseną [39].

\section{Išvados}

1. Motinos sveikatos raštingumas reikšmingas néštumo eigai, gimdymui ir naujagimio priežiūros kokybei bei sveikatos elgsenai nèštumo metu.

2. Teisiniai reglamentai nustato motinų galimybę gauti kokybišką něščiujų, naujagimio sveikatos priežiūrą bei užtikrinti paslaugų prieinamumą, tačiau motinų sveikatos raštingumo ugdymo galimybès, neįtrauktos ị néščiųų priežiūros paslaugų paketą, nèra privalomos.

3. Teisiniai reglamentai nurodo akušerių praktikos veiklą bei leidžia veikti savarankiškai, vykdyti švietejiš̌ką motinu sveikatos raštingumo veiklą, skatinant tinkamą motinos sveikatos priežiūrą bei naujagimio poreikių užtikrinimą

4. Në̌̌čiajai, sergančiai COVID-19 infekcija, sveikatos priežiūros paslauga teikiama remiantis sveikatos apsaugos ministro patvirtintu aprašu [27], tretinio lygio stacionare.

\section{Literatūra}

1. What is the efficacy/effectiveness of antenatal care and the financial and organizational implications? WHO Regional Office for Europe's Health Evidence Network (HEN) 2018. https:// www.euro.who.int/en
2. LR SAM. Akušerijos diagnostikos ir gydymo metodikos, 2019. https://sam.lrv.lt/lt/veiklos-sritys/programos-ir-projektai/ sveicarijos-paramos-programa/akuserijos-ir-neonatologijosdiagnostikos-ir-gydymo-metodikos/akuserijos-diagnostikosir-gydymo-metodikos

3. Nėštumas, gimdymas ir laikotarpis po gimdymo. TLK-10-AM / ACHI / ACS elektroninis vadovas. http://ebook.vlk.lt/e.vadovas/index.jsp?topic=/lt.webmedia.vlk.drg.icd.ebook.content/ $\mathrm{html} / \mathrm{icd} / 15$ skyrius.html

4. Azugbene E. Maternal health literacy and maternal and child health outcomes: a review of the literature. Annals of Global Health 2017;83(1):94.

https://doi.org/10.1016/j.aogh.2017.03.208

5. Kilfoyle KA, Vitko M, O'Conor R, Bailey SC. Health literacy and women's reproductive health: a systematic review. J Womens Health (Larchmt). 2016;25(12):1237-1255.

https://doi.org/10.1089/jwh.2016.5810

6. Liepinaitienè A., Čerkauskaitė S., Tamošiūnas A. Pagimdžiusių moterų gimdymo patirčių vertinimas moterų nuomone. II nacionalinès visuomenès sveikatos konferencijos „Lyderyste sveikatai - sveikata lyderystei“ tezių knyga. Kaunas, 2017. http://www.1smuni.lt/media/dynamic/files/12947/vskonferencija_2017.pdf

7. Rowlands G, Russell S, O'Donnell A, et all. What is the evidence on existing policies and linked activities and their effectiveness for improving health literacy at national, regional and organizational levels in the WHO European Region? Copenhagen: WHO Regional Office for Europe 2018. https://www.euro. who.int/en/publications/abstracts/what-is-the-evidence-onexisting-policies-and-linked-activities-and-their-effectivenessfor-improving-health-literacy-at-national,-regional-and-organizational-levels-in-the-who-european-region-2018

8. Ratzan SC. Health literacy: communication for the public good. Health Promotion International 2001;16(2):207-214.

https://doi.org/10.1093/heapro/16.2.207

9. Nutbeam D. Health literacy as a public health goal: a challenge for contemporary health education and communication strategies into the 21 st century. Health Promotion International, 2000;3:259-267.

https://doi.org/10.1093/heapro/15.3.259

10. Skeirienė A. Motinystès mokyklos poreikio vertinimas. Magistro diplominis darbas. Launas, LSMU, 2012. https://www. 1smuni.lt/cris/bitstream/20.500.12512/102661/1/darbas.pdf

11. Khorasani EC, Peyman N, Esmaily H. Relations between breastfeeding self-efficacy and maternal health literacy among pregnant women. 2016. https://ebcj.mums.ac.ir/article_7986. html\#_ENREF

12. Ghanbari S, Majlessi F, Ghaffari M, Majdabadi MM. Evaluation of health literacy of pregnant women in urban health centers of Shahid Beheshti Medical University. Daneshvar (Persian). 2012;19(97):1-12 https://jfrh.tums.ac.ir/index.php/jfrh/article/ view/683

13. Dilmore DL. A comparison of confidence levels of postpartum 
depressed and nondepressed first-time mothers: summary of master thesis. The Florida state university 2014. https://guides. lib.fsu.edu/c.php?g=352562\&p=2380945

14. Nutbeam D, McGill B, Premkumar P. Improving health literacy in community population: a review of progress. Health Promotion International 2018;33(5):901-911.

https://doi.org/10.1093/heapro/dax015

15. Julie M, Cooper BS, Marguerite R. Health literacy in practice program, evaluation report. Western Michigan University. Michigan: School of Social Work, Educare of Southwest Michigan; 2011:1-156. http://jrh.gmu.ac.ir/article-1-261-en.pdf

16. World Health Organization. Division of health promotion, education and communications health education and health promotion Unit. Geneva, Switzerland: Health Promotion Glossary 1998. https://www.who.int/healthpromotion/about/ HPR\%20Glossary\%201998.pdf

17. Mobley SC, Thomas SD, Sutherland DE, Hudgins J, Ange B, Johnson M. Maternal health literacy progression among rural perinatal women. Matern Child Health J. 2014;18(8):1881-92. https://doi.org/10.1007/s10995-014-1432-0

18. Ferguson B. Health literacy and health disparities: the role they play in maternal and child health, nurs womens health 2008;12(4):286-98. https://doi.org/10.1111/j.1751-486X.2008.00343.x

19. Okan O, Bauer U, Levin-Zamir D, Pinhero P. Improving health literacy in community population: a rewiew of progress. Health Promot Int 2018:33(5):901-911. https://doi.org/10.1093/ heapro/dax015

20. Azugbene E. Maternal health literacy and maternal and child health outcomes: a review of the literature. Annals of Global Health 2017;83(1):94. https://doi.org/10.1016/j.aogh.2017.03.208

21. Khorasani EC, Peyman N, Esmaily H. Measuring maternal health literacy in pregnant women referred to the healthcare centers of Mashhad, Iran, in 2015. J Midwifery Reprod Heal 2018;6(1):1157-62.https://jmrh.mums.ac.ir/article_9613.html

22. D'Ambrosio A, Writer S. Mom's Low Health Literacy Puts Herself and Her Newborn at Risk. MedPage Today 2020. https:// www.medpagetoday.com/meetingcoverage/smfm/84785

23. Azugbene E. Maternal health literacy and maternal and child health outcomes: a review of the literature, 2019. https://www. researchgate.net/publication/315944645_Maternal_Health_Literacy_and_Maternal_and_Child_Health_Outcomes_A_Review_of_the_Literature

24. Julie M, Cooper BS, Marguerite R. Health literacy in practice program, evaluation report. Western Michigan University. Michigan: School of Social Work, Educare of Southwest Michigan 2011:1-156 http://jrh.gmu.ac.ir/article-1-261-en.pdf;

25. Eurostat statistics. https://ec.europa.eu/eurostat/statisticsexplained/index.php?title $=$ Archive: Region $\%$ C5\%B3 demografin $\% C 4 \% 97$ statistika\&oldid=196665; https:// ec.europa.eu/eurostat/databrowser/view/demo_minfind/ default/table?lang=en
26. Lietuvos - Šveicarijos bendradarbiavimo programa. https:// sam.lrv.lt/lt/veiklos-sritys/programos-ir-projektai/sveicarijosparamos-programa/apie-lietuvos-ir-sveicarijos-bendradarbiavimo-programa

27. Sveikatos apsaugos ministro $2013 \mathrm{~m}$. rugsèjo $23 \mathrm{~d}$. įsakymas Nr. V-900 „Dèl Něščiųjų, gimdyvių ir naujagimių sveikatos priežiūros tvarkos aprašo patvirtinimo“". https://e-seimas.lrs.lt/ portal/legalAct/lt/TAD/TAIS.456692?jfwid=16rzjwirj1

28. Sveikatos apsaugos ministerija. Geros akušerinès praktikos gairès. Antenatalinė priežiūra. Metodika. https://sam.lrv.lt/uploads/ sam/documents/files/Veiklos_sritys/Programos_ir_projektai/ Sveicarijos_parama/Akuserines\%20metodikos/Antenataline\%20prieziura.pdf

29. Kaminskienẻ V. Nėščiųjų moterų pasiruošimo motinystei ir ji įtakojančių veiksnių tyrimas. Magistro diplominis darbas. Kaunas, LSMU 2018. https://www.lsmuni.lt/cris/bitstream/20.500.12512/102661/1/darbas.pdf

30. Liepinaitienė A., Poškienė I. Moterų gimdymo ir pogimdyminès priežiūros lūkesčių vertinimas moterų nuomone. Sveikatos mokslai, 2016;26(6):201-206

https://doi.org/10.5200/sm-hs.2016.117

31. Baqui AH, Mitra DK, Begum N, et al. Neonatal mortality within 24 hours of birth six low and middle income countries. 2016. https://doi.org/10.2471/BLT.15.160945

32. Persson E, Fridlund B, Kvist L. Fathers' sense of security during the first postnatal week - a qualitative interview study in Sweden. Midwifery 2011:22(5):697-704. https://doi.org/10.1016/j.midw.2011.08.010

33. Werner-Bierwisch T, Pinkert C, Niessen K, et al. Mothers' and fathers' sense of security in the context of pregnancy, childbirth and the postnatal period: an integrative literature review. BMC Pregnancy and Childbirth 2018;18(1):473. https://doi.org/10.1186/s12884-018-2096-3

34. Morkūnaitė A, Pinkevičiūtė A, Machtejevienė E, Kliučinskas M. Akušerès ir gydytojo priežiūros palyginimas mažos rizikos gimdymo metu Kauno klinikose. Lietuvos akušerija ir ginekologija 2015;15(1):8-14.

35. LR sveikatos apsaugos ministro $2014 \mathrm{~m}$. lapkričio $25 \mathrm{~d}$. įsakymas Nr. V-1220 „Dèl Lietuvos medicinos normos MN 40:2014 „Akušeris. Teisès, pareigos, kompetencija ir atsakomybe்“ patvirtinimo". https://www.e-tar.lt/portal/lt/legalAct/1bdf86b 076cb11e49710918558376243

36. Slaugos praktikos ir akušerijos praktikos įstatymas IX-413. 2019. https://e-seimas.lrs.lt/portal/legalAct/lt/TAP/e1a75ae0 06da11 ea87aaea1d28b191f8?jfwid=-16sfl5zejw

37. Timothy J, et al. Pregnant during the COVID-19 crisis. Taking care of your mental health Medically MSN, CRNA 2020. https://www.medicalnewstoday.com/articles/covid-19-pregnancy-and-mental-health

38. WHO Coronavirus disease 2019 (COVID-2019) situation report 46. 2020. https://www.who.int/docs/default-source/ coronaviruse/situation-reports/20200306-sitrep-46-covid-19. pdf?sfvrsn=96b04adf_2 
39. Sveikatos apsaugos ministerija. COVID - 19 infekcija ir nèštumas. Informacija pacientėms ir jų artimiesiems. https://sam. lrv.lt/uploads/sam/documents/files/KORONA/COVID-19\%20 Paciente\%CC\%87ms\%202020\%2004\%2006.pdf

40. Higienos institutas. Lietuvos visuomenès sveikatos pokyčiu apžvalga. Vilnius, 2019.https://hi.lt/uploads/pdf/leidiniai/ Informaciniai/Visuomenes_sveikatos_pokyciu_\%20apzvalga_2019.pdf

\section{POSSIBILITIES OF PREGNANT WOMEN HEALTH LITERACY DEVELOPMENT IN HEALTH CARE: ANALYSIS OF LEGAL REGULATIONS}

A. Gaupšienė, J.Šuminienè, R. Stukas, J. Kutkauskienė, N. Fatkulina

Keywords: maternal health literacy, maternal health care and analysis of legal regulations, midwifery competence, COVID-19 infection during pregnancy.

Summary

Maternal informativeness and maternal health literacy are important factor in maternal health care. In this case, the relationship with health care providers, oriented to the impeccable behavior of the mother during pregnancy, uncomplicated course of pregnancy, childbirth and nursing care is very important. In Lithuania, the health care of pregnant women is carried out in accordance with the procedure provided for in legal acts, giving pregnant women the opportunity to choose a health care specialist - obstetrician, gynecologist, family doctor, midwife during physiological pregnancy, childbirth and a healthy newborn. The legislation specifies health care services for pregnant women, outpatient care (7-8 times) during the physiological course of pregnancy and the possibility for a pregnant woman to choose a maternity hospital according to her health condition and personal discretion. Services are free of charge (for socially insured patients), reimbursed by territorial health insurance funds. However, pregnant women training service is non-specified, developing health literacy and access to training courses for pregnant women by funding them from public hospital funds. The choice is up to the pregnant woman, optional, unregulated is not legitimized by a uniform standard.

The aim of the research is to analyze the current Lithuanian legal acts regulating the provision of maternal health care services, opportunities and peculiarities of maternal health literacy education, midwifery competence and opportunities in maternal health literacy development.

The results and discussion. Overview of maternal health literacy definitions, forms maternal health literacy as a set of individual social and cognitive skills, health literacy level and education related to good maternal knowledge and understanding concept and access to and reliance on new health information. Maternal health literacy is significant in maternal and neonatal health care and health behaviors. Requirements for the care of pregnant women are defined by international cooperation programs, methodologies, algorithms, regulations issued by the government. Antenatal care methodology specifies the exact number of visits during physiological pregnancy and course, priority is given to understanding, listening, but maternal health literacy is not included as a necessary educational tool, teaching mothers (parents) proper health behaviors during pregnancy, newborn care skills.

Information for pregnant women is received from the family doctor or obstetrician-gynecologist during the visit, but the information is limited due to the duration and amount of the visit. the process of developing health literacy, referred to as - a sequence of actions in which certain elements interact with each other - the aim and content of teaching, the method and means of education and the role of the educator. The role of maternal health literacy educator can be performed by a midwife, but there is no developed methodology, there is no uniform standard, training for pregnant women and other educational activities are not obligatory or funded.

Correspondence to: alma.gaupsiene@vu.mf.lt

Gauta 2021-03-05 